\title{
The Impact of Online Shopping on Traditional Vendors at Petisah Market Medan.
}

\author{
Rudianto Sipahutar \\ \{rudiantosipahutar13@gmail.com\}
}

Postgraduate Program, Pelita Kebenaran School of Theology

\begin{abstract}
The aim of the current study is to determine the impact of online shopping on traditional market vendors in Medan Petisah Market. The research is qualitative, where obtaining research data was conducted by interviews with traditional market vendors in the Petisah Market. From the results it was found that the wide spread of online shopping nowadays caused a decrease in average monthly income of Rp. 27,500,000 (10.05\%). Most affected by online shopping is clothing businesses by $18.89 \%$ (Rp. 3,666,667). Traders of household needs feel less of the impact of online shopping, experiencing a decrease of only Rp. 1,500,000 (8.77\%).
\end{abstract}

Keywords: Online shopping, pasar tradisional, pedagang, e-marketing, e-commerce.

\section{Introduction}

Advancement in information technology in the last two decades has caused a paradigm shift, one of which is the birth of a new model of buying and selling, namely online shopping or also called e-commerce. E-commerce includes purchasing, marketing, sales, service to shipping and payment between networked companies, with customers, suppliers and other business partners, which all are done through internet network. The benefits that consumers of e-commerce get include competitive pricing (comparing prices and features to get the best products); ease of transactions wherever and whenever; and get services in accordance with preferences and personal needs. E-commerce provides a great opportunity for marketers to reduce costs and increase customer satisfaction through faster, more interactive, realtime and efficient services, this potential is supported by a number of capabilities and global capabilities to reach anyone connected to the internet anywhere. The segmentation of this online market is from teenagers who are still in school, students, to adults of various ages and occupations. They began to develop creativity and innovation to try their luck and develop business in the online world. This is a positive impact on many fields, such as trade and the economy, from the rapid development of technology that ruled the world in recent years.

According to Armstrong and Kotler, e-marketing involves the company's efforts to inform, communicate, promote and market products and services online. The existence of emarketing is one of the promising alternative promotions to be implemented at this time, because e-marketing provides various facilities for both parties, both from the company and from the public (consumers). The advantages of e-marketing can be described in the picture below. 


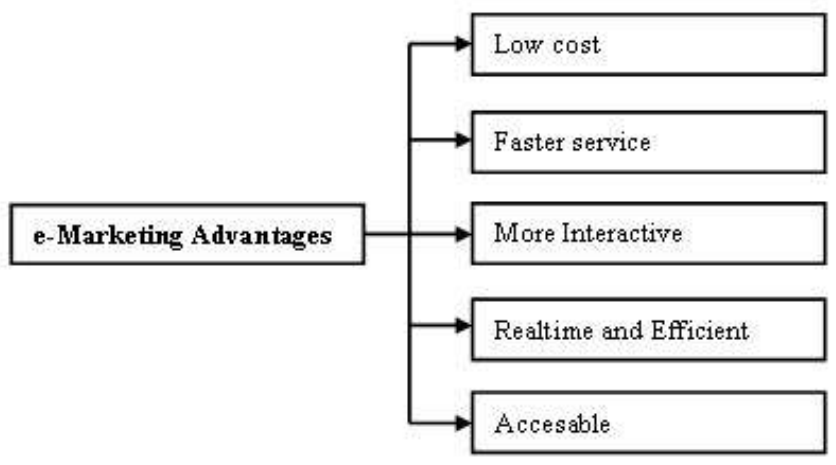

Fig.1.Advantages of e-Marketing

Traditional markets play an important role in the economic growth in Indonesia and have natural competitive advantages. Traditional market is very helpful, not only for the regional or central government but also for the people who depend on trading activities, because in traditional markets there are many actors who have important meaning and try to prosper their lives both traders, buyers, pelvic workers etc. They are all actors who play an important role in maintaining the existence of traditional markets in Indonesia.

Petisah Market afamous traditional market in Medan. The market is the same age as Medan City, is always crowded with buyers, including travelers who come from outside the city of Medan. One of the features of this market lies in its location in the center of Medan, making it easier for travelers to reach it, in addition to the multicultural look of the market.

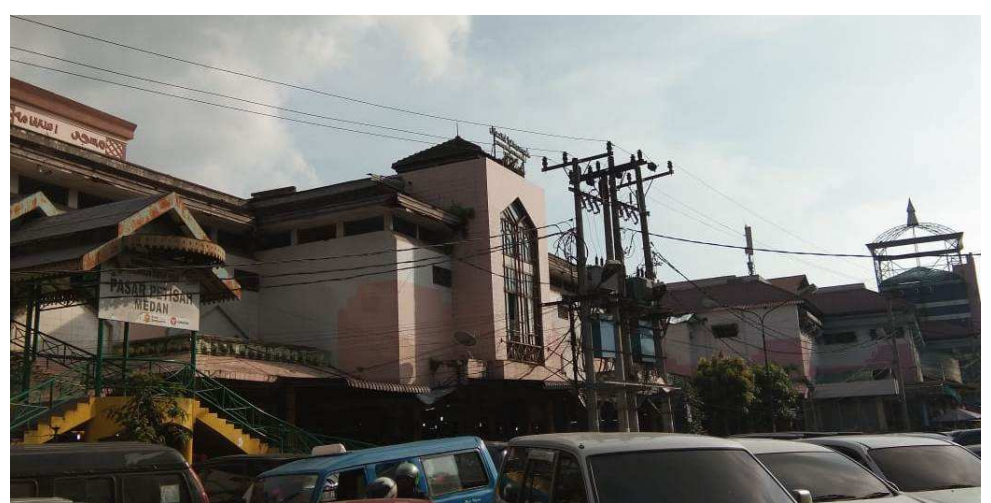

Fig. 2.Medan Petisah Market

The advances of online shopping has impacted negatively the traditional traders in the Petisah market. Economic activities in traditional markets are declining because the market share is indirectly seized by online traders. Based on the purpose of the purchase, online shoping consumers can be divided into two 


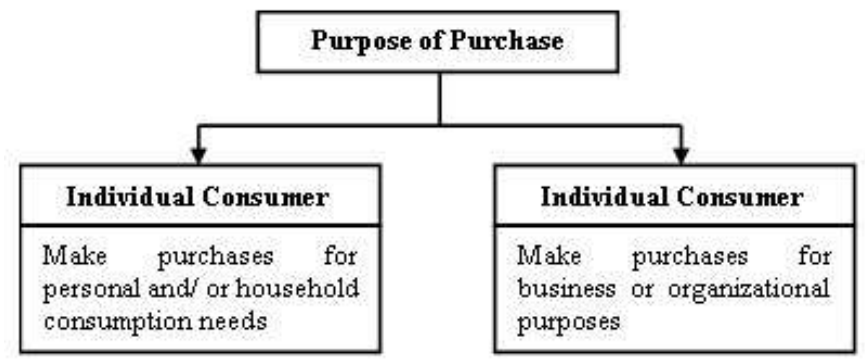

Fig. 3.Pupose of Purchase

\section{Research Method}

The method used in this research is qualitative research, in which data is obtained through research. The research model is selected because it is more flexible and centered on the subject of research.

\subsection{Population}

The population of this study is traditional market traders which is still actively in Medan Petisah, located at Market, Jl Kota Baru Tengah, Medan Petisah-Medan. The method of sampling is simple random sampling, the number of samples taken is 18 stalls.

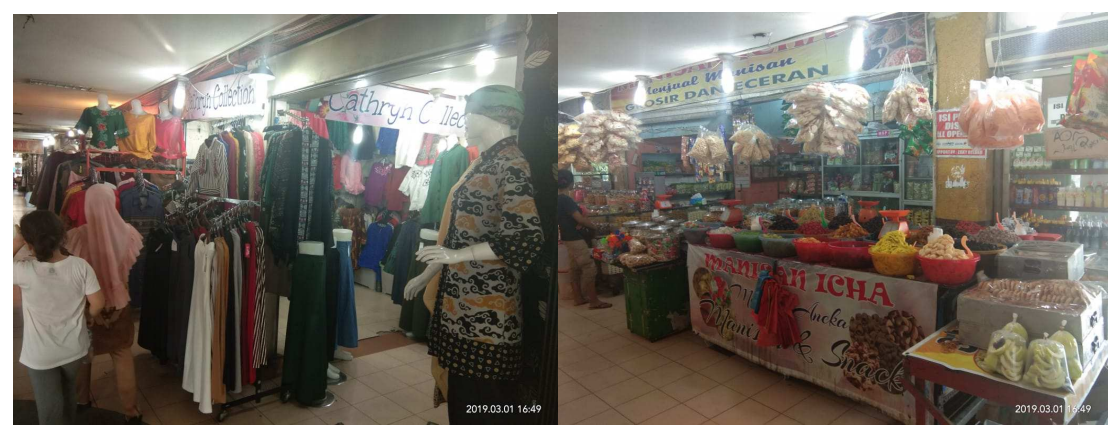

Fig.4. Stall in Medan Petisah Market

\subsection{Data Collection}

Data collecting was mainly done by interviewing traders at Medan Petisah Market. The purpose was to find out the impact of online-based sales on turnover of traders. Interview is a meeting of two people to exchange information and ideas through question and answer so that meaning can be constructed in a particular topic and with interviews, researchers will know things that are more in-depth about participants in interpreting situations and phenomena that occur that cannot be found through observation. In this case the researcher asked directly about the condition of the results of the trading business in the last 2 (two) years, as a result of the development of online shopping. 


\section{Result and Discussion}

Based on the analysis, the results from Petisah showsa significant impact on traders by the presence of the online market. There is a decline in profits where profits have decreased in the past year compared to previous years. Likewise, when viewed from the aspect of turnover, there are significant differences, traditional traders feel competition, so that strategies to compete, traditional market traders apply lower prices in the bargaining process (lower profit percentage), with the aim of obtaining regular customers or so consumers do not move to the online market. the existence of an online-based market will have the effect of reducing the number of consumers who shop in traditional markets, because segmentation will occur. Not all consumers like the transaction process through bargaining, because consumers must provide time to find a price agreement with the seller. A price agreement will occur if the seller is willing to sell at a price level that is considered profitable and the consumer is willing to buy at that price level, but in order for equality of information, consumers still have to compare the price of goods between one store and another.

The impact e-commerce on the number of types of goods traded in the Petisah market has decreased, as well as the number of buyers, number of suppliers, and number of workers, which has decreased after the online market, which means that the number of buyers, number of suppliers and number of workers in smaller traditional markets. Which shows that the number of buyers declined in traditional markets due to the online market. Decreasing consumers in traditional markets due to the lack of quality of shopping convenience they get when they shop in traditional markets, so consumers feel uncomfortable and will move to online markets with more convenient shopping facilities.

Trading using face-to-face method and undergoing a process of bargaining is an old habit that has begun to be abandoned by consumers. They choose to relax at home while waiting for the ordered items to arrive. This saving time and energy certainly leaves a risk for traditional businesses. Split market images are influenced by the variety of products offered, distance of location and various other considerations. For example, people now prefer to travel using online transportation rather than jostling inside the bus or waiting long to find a motorcycle taxi base. This problem will continue to erode the existence of traditional or offline traders. The world is progressing, the demands of society are increasing in terms of convenience and time efficiency. Even though they have their own fans, traditional traders must have as much added value as possible in order to survive in the modern digital era.

Based on the results of interviews with traders in the Petisah market, the impact of online traders on market traders is separate, then get the results in the following table:

Tabel 1. Decreased earnings of Petisah traders in 2017 - 2018 (average / month)

\begin{tabular}{lllll}
\hline \multicolumn{1}{c}{ Type of Business } & $\begin{array}{c}\text { Merchant } \\
\text { Sampel }\end{array}$ & $\mathbf{2 0 1 7}$ & $\mathbf{2 0 1 8 ,}$ & $\begin{array}{c}\text { Decreaded Ratio } \\
\text { (\%) }\end{array}$ \\
\hline Fresh Fruit Traders & 1 & 12.000 .000 & 10.000 .000 & 16.67 \\
& 2 & 16.500 .000 & 13.000 .000 & 15.63 \\
Shoes, Sandals and Smilar & 3 & 14.000 .000 & 12.000 .000 & 14.29 \\
Traders & 1 & 10.000 .000 & 7.500 .000 & 25 \\
& 2 & 7.000 .000 & 6.000 .000 & 14.3 \\
Cloting/ Fashion Traders & 3 & 9.000 .000 & 8.000 .000 & 11.1 \\
& 1 & 25.000 .000 & 20.000 .000 & 20 \\
& 2 & 18.000 .000 & 15.000 .000 & 16.67 \\
Snack and Cake Traders & 3 & 15.000 .000 & 12.000 .000 & 20 \\
& 1 & 18.000 .000 & 15.000 .000 & 16.67 \\
\hline
\end{tabular}




\begin{tabular}{lllll}
\hline & 2 & 16.000 .000 & 13.500 .000 & 15.63 \\
Toys and Tableware Traders & 3 & 13.000 .000 & 11.000 .000 & 15.38 \\
& 1 & 30.000 .000 & 25.000 .000 & 16.67 \\
& 2 & 21.000 .000 & 18.000 .000 & 14.3 \\
Basic Foods and Household & 3 & 18.000 .000 & 16.000 .000 & 11.11 \\
Needs Traders & 1 & 20.000 .000 & 17.500 .000 & 12.5 \\
& 2 & 15.000 .000 & 14.000 .000 & 6.67 \\
Total & 3 & 14.000 .000 & 13.000 .000 & 7.14 \\
\hline
\end{tabular}

Based on the table above, traders in the Petisah market as a whole experience a decrease in average income per month of Rp. 27,500,000 (10.05\%). The most affected by the impact of online sales is the fashion traders group, which has decreased by Rp. 3,666,667 (18.89\%). Traders who feel less of the impact of online shopping are the needs of households, only a decrease of Rp. 1,500,000 (8.77\%). For the decrease in income of each trader, the decrease in income most experienced by shoes / sandals traders, sample 1 which decreased by $25 \%$, while for the lowest decline experienced by traders of household needs, only $6.67 \%$. From this, it can be concluded that the existence of an online market has a negative impact on the income of market traders.

\section{Conclution}

Based on the results of the research, it can be seen that the advanceing trend of online shopping has a negative impact on traditional traders in Petisah Market, Medan. Online shopping results in a decline in sales turnover of traditional market traders. Therefore, it is expected for stakeholders to anticipate these findings by making policies that also favor traditional market traders. This finding is intended as input for subsequent research with larger locus and samples so that it can provide input for the government in determining policies in the regions or nationally.

\section{References}

[1] Ester dan Didik. Membuat Pasar Tradisional Tetap Eksis. Jakarta Sinar Harapan 2003

[2] Fandy, Tjiptono dan Diana Anastasia.: Pemasaran, Esensi dan Aplikasi. pp. 54. Andi, Yogyakarta 2017

[3] Fandy, Tjiptono Fandi dan Chandra Gregorius.: Pemasaran Stategik. pp. 162. Andi, Yogyakarta 2017

[4] Humdiyana dan Indriyani, Sistem Informasi Manajemen Bisnis, (Yogyakarta, Graha Ilmu, 2005

[5] Kotler, Philip dan Gary Armstrong. Prinsip-prinsip Pemasaran ; Jakarta: Erlangga 2009

[6] Noor, Juliansyah.: Metodologi Penelitian. pp. 137. Prenadamedia Group, Jakarta 2015

[7] Nugroho Adi , Memahani perdagangan Modern di dunia Maya, Bandung, Informatika, 2006

[8] Riyeke Ustadiyanto. e-Business Plan : Perencanaan, Pembangunan dan Strategi di Internet, Yogyakarta Penerbit ANDI, 2007

[9] Sugiono. Metode Penelitian Pendekatan Kuantitatif, Kualitatif dan R \& D. Bandung: Alfa Beta 2009

[10] Wirawan.: Evaluasi: Teori, Model, Metodologi, Standar, Aplikasi dan Profesi. pp. 211. RajaGrafindo Persada, Jakarta 2016 